\title{
VARŽYBINĖS VEIKLOS RODIKLIŲ SKIRTUMAI TARP LAIMĖJUSIŲ IR PRALAIMĖJUSIŲ KREPŠINIO KOMANDŲ
}

\author{
Rasa Kreivytè, Antanas Čižauskas \\ Lietuvos kūno kultūros akademija, Kaunas, Lietuva
}

\begin{abstract}
Rasa Kreivytė. Edukologijos mokslų krypties doktorantė. Lietuvos kūno kultūros akademijos Sportinių žaidimų katedros asistentė. Moksliniu
\end{abstract} tyrimų kryptis - didelio meistriškumo moterų krepšinio komandų varžybinès veiklos analizè.

\section{SANTRAUKA}

Svarbiausi kriterijai, apibūdinantys krepšininku ir komandu žaidima, yra varžybinès veiklos rodikliai, ju kaita pagrindinèse varžybose. Tai kartu labai svarbi moksliniu tyrimu sritis. Norédami parengti krepšinio komanda rungtynèms, sukurti geriausia taktika, atlikti teisingus sprendimus per rungtynes, treneriai turi žinoti, kurie žaidimo elementai yra svarbiausi siekiant pergalès. Ypač tai svarbu, kai rungtynès yra įtemptos ir tik nedidelis rezultatu skirtumas skiria dvi tarpusavyje rungtyniaujančias komandas.

Pagrindinis tyrimo tikslas — nustatyti kritinius žaidimo veiklos rodiklius tarp laimèjusiu ir pralaimëjusiu moteru krepšinio komandu.

Tyrimo duomenys buvo analizuojami pagal Europos čempionato rungtyniu $(n=54)$ specialius techninius protokolus, parengtus oficialiame čempionato puslapyje. Klasterinè analize buvo taikoma norint visas Europos čempionato rungtynes suskirstyti i tris tipus: rungtynes, kurios baigèsi nedideliu (1-9), vidutiniu (10-21) ir dideliu (22-34) tašku skirtumu. 31 iš visu čempionato rungtyniu vyko taškas ì taška, o skirtumas tarp komandu buvo 9 ar mažiau tašku. Lyginant laimèjusiu ir pralaimëjusiu komandu 18 žaidimo rodikliu, buvo taikoma Vilkoksono (Wilcoxon) ženklu kriterijus. Nustatyta 10 reikšmingu žaidimo veiklos rodikliu analizuojant visas čempionato rungtynes. Rungtynèse, kurios baigèsi mažu tašku skirtumu, reikšmingas rodikliu skirtumas tarp komandu sumažèjo iki 7.

Reikšmingiausias rodikliu skirtumas, lemiantis pergalę, buvo toks: pelnomu tašku skaičius (p <0,001), mestu baudos metimu ( $p<0,001)$, ginantis $(p<0,001)$ ir iš viso atkovotu kamuoliu skaičius $(p<0,001)$.

Svarbiausi žaidimo veiklos rodikliai, kurie lemé pergalę įtemptose rungtynèse, buvo toks: ginantis $(p<0,01)$, iš viso atkovotu kamuoliu $(p<0,01)$ ir asmeniniu pražangu $(p<0,01)$ skaičius. Itemptose rungtynèse laimèjusios komandos mažiau meta iš tolimo nuotolio $(p<0,05)$, tačiau ju tikslumas yra geresnis $(p<0,05)$.

Rezultatai, gauti atlikus rungtyniu, kurios baigèsi vidutiniu ir dideliu tašku skirtumu, varžybinès veiklos analize rodo, kad laimejusiu komandu rodikliai buvo geresni beveik visais statistiniais žaidimo rodikliais.

Raktažodžiai: krepšinis, žaidimo analizè, žaidimo veiklos rodikliai.

\section{IVADAS}

$\check{Z}$ aidimo rodikliai yra registruojami norint ivertinti žaidèjo, grupès ar komandos veiklą (Hughes, Bartlett, 2002; Kreivytè, Čižauskas, 2007). Žaidimo rodikliai padeda treneriams nustatyti gerą ar blogą žaidèjo ar komandos varžybinę veiklą (Bartlett, 2001; Hughes, Franks 1997, 2004, 2008).

Žaidimo veiklos rodikliai dažnai analizuojami norint nustatyti laimejjusių ir pralaimejjusių koman- dų skirtumus. Norėdami sukurti geriausią žaidimo strategiją, padedančią priimti racionalius taktinius sprendimus ir sustiprinti komandos žaidimo veiklą, treneriai turi žinoti, kurie žaidimo elementai reikšmingai skiriasi, kurie labiausiai lemia pergalę krepšinio rungtynèse.

Tarptautinè krepšinio federacija (FIBA) nustatè 18 varžybinès veiklos rodiklių, kurie yra oficialiai registruojami kiekvienose rungtynèse. 
Dauguma ankstesnių varžybinès veiklos tyrimu atlikti analizuojant pagrindinius oficialius statistinius rodiklius.

Nuo 1992 iki 2000 metų S. Trninic ir kt. (2002) tyrinejjo rungtynes laimejjusiu ir pralaimejusiu komandu varžybinès veiklos skirtumus, Europos klubinių komandų finalinio ketverto rungtynes. Jie nustatè, kad atkovotų kamuolių skaičius ginantis, metimų ir baudos metimų tikslumas buvo lemiami veiksniai siekiant pergalès.

Kiti tyrejai (Mendes, Janeira, 2001; Tsamourtzis et al., 2005) nustaté, kad atkovotų kamuolių skaičius ginantis krepšinio rungtynèse yra pagrindinis veiksnys, kuris skiria laimejjusią ir pralaimejusią komandą. 1997 m. per Europos vyrų krepšinio čempionatą nustatytas reikšmingas metimu i krepši, rezultatyvaus perdavimo ir tiksliu baudos metimu skaičiaus skirtumas tarp laimejjusių ir pralaimejjusių komandų (Jukic et al., 2000).

R. Lidor ir M. Arnon (2000) nustatè, kad sèkmès rungtynèse negali lemti vien tik metimai i krepšit, komandos žaidejjai turi rodyti aukštus rodiklius ir kovodami dèl atšokusio nuo lentos kamuolio, ir rezultatyviai perduodami kamuoli partneriui.

J. Sampaio ir kt. (2004) nustatytus varžybinès veiklos rodiklius lygino lyties požiūriu. Vyru komandos keli rodikliai kur kas aukštesni, lyginant su moterų komandomis (blokuotų kamuolių, tikslių metimu iš arti ir vidutinio nuotolio skaičiumi), tačiau moterys dažniau perima kamuoli nei vyrai.

H. Choi ir kt. (2006) taikè Vilkoksono (Wilcoxon) ženklų kriterijų, noredami nustatyti kritinius varžybinès veiklos rodiklius krepšinio rungtynèse. 10 Anglijos krepšinio lygos rungtyniu buvo analizuojamos pagal visų rungtynių ir atskirų kèlinių duomenis. Daugiau skirtingų žaidimo rodiklių jie nustatė analizuodami visų rungtynių veiklos seka, negu analizuodami atskirų kèlinių eigą - varžybinè veikla per rungtynes kinta.

D. Oliver (2004) teigia, kad keturi veiksniai gali būti lemiami siekiant pergalès krepšinio rungtynèse - tai metimų $\mathfrak{i}$ krepši tikslumas, puolimo metu atkovotų kamuoliu, baudos metimų ir technikos klaidų skaičius.

Anot J. Sampaio ir M. Janeira (2003), varžybinès veiklos rodiklius lemia žaidimo vieta (kur vyksta rungtynès - namie ar išvykoje) ir rungtyniu tipas (reguliaraus sezono, atkrintamosios ar finalinès). 1997-1998 ir 1998-1999 m. Portugalijos krepšinio lygos reguliariojo sezono rung- tynėse išvykoje laimi komanda, ryškiai išsiskyrusi tikslių baudos metimų skaičiumi. Atkrintamosiose ir finalinėse rungtynèse ji ryškiai išsiskyre puolimo metu atkovotų kamuolių skaičiumi, namie rungtyniaudami laimètojai dažniau išprovokuodavo pražangas.

Analizuodamas įvairių rungtynių tipus, J. Sampaio ir M. Janeira (2003) taikè klasterinès analizès metodą ir bande išskirti tris skirtingas rungtyniu grupes pagal galutini rungtynių rezultato skirtumą.

F. Tavares ir N. Gomes (2003) nustatè, kad pelnomų taškų, baudos metimų tikslumo, pražangų ir puolimo metu atkovotų kamuoliu skaičiaus rodikliai rungtynėse smarkiai skyrèsi žaidžiant didelio meistriškumo vaikinu (jaunimo) komandoms.

G. M. A. Reano ir kt. autoriu tyrimu (2006) nustatyti tarpusavyje susiję rungtynių žaidimo statistiniai rodikliai, kurie atskleidè pagrindinius skirtumus tarp $2004 \mathrm{~m}$. Europos čempionate laimejjusių ir pralaimejjusių komandų U16 (jaunučių). Taikant klasterinès analizès metodą, rungtynès buvo suskirstytos į tris grupes: rungtynès, kurios baigèsi nedideliu tašku skirtumu, pasibaigusios vidutiniu ir dideliu taškų skirtumu. Nustatyta, kad per rungtynes, kurios baigèsi nedideliu taškų skirtumu, ryškiai skyrèsi tiksliu metimu iš tolimo nuotolio skaičius bei rezultatyvių perdavimų skaičius tarp laimèjusių ir pralaimejjusių komandų.

Ivairių krepšinio turnyrų rungtynių analizè tai esminių žaidimo rodiklių skirtumo nustatymas tarp dviejų komandų. Kai rungtynès yra apgalvotos ir vertinamos, rungtyniu varžybinès veiklos rodiklių skaičius smarkiai didejja.

Rungtynèse, kurios vyksta taškas i tašką ir baigiasi mažu taškų skirtumu, didelị vaidmeni ir atsakomybę už komandinès taktikos formavimą siekiant pergalès atlieka treneriai. Tokių svarbiu rungtynių analizès rezultatai suteikia naudingos informacijos apie svarbiausius žaidimo elementus, kurie nulemia skirtumus tarp komandų laimètojų ir pralaimètojų. Lemiamu varžybinès veiklos rodikliu žinojimas leidžia treneriams pasirengti tikslesnes rungtynių schemas ir sukurti geriausią žaidimo strategiją siekiant pergalès.

Pagrindinis šio tyrimo tikslas - nustatyti kritinius žaidimo veiklos rodiklius tarp laimèjusių ir pralaimèjusių moterų krepšinio komandu skirtingo tipo 2009 m. Europos čempionato rungtynèse. 


\section{TYRIMO METODIKA}

Atlikta 2009 m. Europos moterų krepšinio čempionato, vykusio Latvijoje, varžybinių rodiklių analizè. Iš viso buvo analizuojamos 54 Europos čempionato rungtynès. Atrankos etape dalyvavo 16 moterų krepšinio komandų, kurios buvo suskirstytos i 4 pogrupius. Tik komandos, pogrupyje užèmusios pirmas tris vietas iš kiekvienos grupès, pateko i kitą kvalifikacini etapa. 4 geriausios šio etapo komandos iš kiekvienos grupès pateko ị ketvirtfinalị ir žaidè dèl $1-8$-ų vietų.

Tyrimo duomenys analizuoti pagal visų Europos čempionato rungtynių specialius techninius protokolus, kurie buvo pateikiami oficialiame čempionato puslapyje (www.fibaeurope.com). Žaidimo veiklos rodikliai yra šie:

- mestų ir tikslių dvitaškių metimų skaičius ir jų tikslumas (\%),

- mestų ir tikslių tritaškių metimų skaičius ir jų tikslumas (\%),

- mestų ir tikslių baudos metimų skaičius ir jų tikslumas (\%),

- atkovotų kamuolių skaičius puolimo metu, ginantis ir iš viso,

- perimtų kamuolių skaičius,

- rezultatyviai perduotų kamuolių skaičius,

- pražangų skaičius,

- technikos klaidų skaičius,

- blokuotų metimų skaičius,

- pelnytų taškų skaičius.

Statistinė analizė. Duomenų analizè atlikta naudojant SPSS for Windows programą. Buvo skaičiuojami gautu tyrimo rodikliu aritmetiniai vidurkiai $(\bar{x})$, standartiniai nuokrypiai. Klasterinè analizė taikyta norint visas Europos čempionato rungtynes suskirstyti $i$ tris tipus: rungtynes, kurios baigèsi nedideliu taškų skirtumu (1-9), rungtynes, pasibaigusias vidutiniu taškų skirtumu $(10-21)$, ir kurios baigèsi dideliu taškų skirtumu (22-34). Norint palyginti laimejusių ir pralaimèjusių komandų 18 žaidimo rodiklių, buvo taikomas Vilkoksono ženklų kriterijus. Skirtumas statistiškai reikšmingas, kai $\mathrm{p}<0,05$.

\section{REZULTATAI}

Ivairių krepšinio turnyrų rungtynių analizè tai esminių žaidimo rodiklių skirtumų nustatymas tarp dviejų komandų. Kai rungtynès yra apgalvotos ir vertinamos, rungtyniu varžybinès veiklos rodiklių skaičius sparčiai didejja.
Varžybinės veiklos rodikliu analizė žaidžiant krepšinį leidžia nustatyti daug tokių rodiklių, kurie yra svarbūs, bet negali būti analizuojami žaidimo metu. Naudojant klasterinę grupių analizę, iš visų čempionato rungtynių buvo išskirtos triju tipu rungtynès, kurių galutinis skirtumas - 9 ir mažiau taškų $(\mathrm{n}=31)$, kurios baigèsi 10-22 taškų skirtu$\mathrm{mu}(\mathrm{n}=17)$ ir didesniu kaip 22 taškai $(\mathrm{n}=6)$.

Viso čempionato metu laimèjusių komandu pelnomų taškų skaičius per vienas rungtynes buvo $68,2 \pm 7,9$, pralaimèjusių $-57,7 \pm 8,3$. Vidutiniškas laimejjusių ir pralaimejjusių komandų taškų skirtumas čempionato rungtynèse buvo 10,5 $(\mathrm{p}<0,001)$.

Metimų i krepši iš arti ir vidutinio nuotolio kiekybiniai rodikliai tarp komandų buvo panašūs (nugalètoju $-41,2 \pm 7,1$, pralaimètojų $-40,7 \pm$ $6,9)$, taip pat metant iš tolimo nuotolio $(5,7 \pm 2,3$ ir $4,9 \pm 2,0)$, tačiau rungtynes laimejjusios komandos dažniau stojo prie baudos metimų linijos $(12,8 \pm$ $5,7$ ir $9,3 \pm 4,0)(p<0,05)$. Šių metimų tikslumas (dvitaškių - 46,8 $\pm 7,9$ ir 41,7 $\pm 6,7 \%$; $<<0,01$, tritaškių - 33,5 $\pm 9,6$ ir 26,5 $\pm 7,4 \%$; $<<0,01$, baudos metimu $-74,5 \pm 11,8$ ir $70,6 \pm 13,5 \%$ ) buvo kur kas geresnis tų komandu, kurios laimejo rungtynes (1 lent.).

Kovodamos dèl atšokusio kamuolio puolimo metu $(11,3 \pm 4,2$ ir 10,9 $\pm 4,9)$ komandos surenka panašų taškų skaičių, ir šių rodiklių skirtumas nèra didelis, tačiau ginantis $(27,6 \pm 3,4$ ir 23,4 $\pm 5,1)$ ir iš viso atkovotų kamuolių skaičiaus rodiklis $(38,9 \pm 5,3$ ir $34,3 \pm 7,2)$ buvo kur kas geresnis nugalètojuc $(\mathrm{p}<0,001)$.

Kiti kiekybiniai žaidimo rodikliai, tokie kaip rezultatyvaus perdavimo $(13,3 \pm 4,0$ ir $10,1 \pm$ $3,4)(\mathrm{p}<0,01)$, asmeninių pražangu $(16,2 \pm 3,8$ ir $19,1 \pm 4,0)(\mathrm{p}<0,01)$ turèjo įtakos siekiant pergalès, o technikos klaidu $(16,2 \pm 3,9$ ir $16,7 \pm$ $4,5)$, perimtu kamuoliu $(8,9 \pm 3,5$ ir $8,0 \pm 2,8)$ ir blokuotų kamuoliu $(2,8 \pm 2,4$ ir $2,0 \pm 1,6)$ skaičius iš esmès nesiskyrè (1 lent.).

Čempionato rungtynių, kurios baigèsi mažu taškų skirtumu (1-9 taškai), buvo 31. Ittemptose rungtynèse, kurios vyko taškas i tašką, nugalèjusios komandos pelnè po $65,7 \pm 6,6$, pralaimèjusios komandos — po $60,6 \pm 6,8$ taško. Vidutiniškai tarp komandų buvo 5,1 taško skirtumas $(\mathrm{p}<0,05)$.

Metimų i krepši kiekybiniai ir kokybiniai rodikliai tokio tipo rungtynèse (dvitaškių metimu skaičius - 41,2 $\pm 7,8$ ir 40,5 $\pm 7,3$, tikslumas $45,0 \pm 6,2$ ir 43,2 $\pm 7,0 \%$ ) neturèjo itakos siekiant pergalès, nes didelio rodiklių skirtumo tarp ko- 


\begin{tabular}{|c|c|c|c|c|c|}
\hline \multirow{17}{*}{$\begin{array}{l}1 \text { lentelè. Visų Europos } \\
\text { čempionato rungtynių ir } \\
\text { rungtynių, kurios baigèsi } \\
1 — 9 \text { taškų skirtumu, var- } \\
\text { žybinių rodiklių analizė }\end{array}$} & \multirow{2}{*}{\begin{tabular}{|l} 
Varžybinis \\
rodiklis
\end{tabular}} & \multicolumn{2}{|c|}{$\begin{array}{l}\text { Visų čempionato } \\
\text { rungtynių }(\mathrm{n}=54)\end{array}$} & \multicolumn{2}{|c|}{$\begin{array}{c}\text { Rungtynių, kurios baigèsi 1-9 } \\
\text { taškų skirtumu }(\mathrm{n}=\mathbf{3 1})\end{array}$} \\
\hline & & $\begin{array}{l}\text { Laimejjusi } \\
\text { komanda } \\
(\bar{x} \pm S)\end{array}$ & $\begin{array}{c}\begin{array}{c}\text { Pralaimèjusi } \\
\text { komanda }\end{array} \\
(\bar{x} \pm S)\end{array}$ & $\begin{array}{c}\begin{array}{c}\text { Laimèjusi } \\
\text { komanda }\end{array} \\
(\bar{x} \pm \mathrm{S})\end{array}$ & $\begin{array}{c}\begin{array}{c}\text { Pralaimejjusi } \\
\text { komanda }\end{array} \\
(\bar{x} \pm \mathrm{S})\end{array}$ \\
\hline & $\begin{array}{l}\text { Imestų metimų iš arti ir vidutinio } \\
\text { nuotolio skaičius }\end{array}$ & $19,1 \pm 4,0 * *$ & $16,9 \pm 3,3$ & $18,4 \pm 3,4$ & $17,3 \pm 3,0$ \\
\hline & $\begin{array}{l}\text { Mestų metimu iš arti ir vidutinio } \\
\text { nuotolio skaičius }\end{array}$ & $41,2 \pm 7,1$ & $40,7 \pm 6,9$ & $41,2 \pm 7,8$ & $40,5 \pm 7,3$ \\
\hline & Dvitaškių tikslumas, \% & $46,8 \pm 7,9 * *$ & $41,7 \pm 6,7$ & $45,0 \pm 6,2$ & $43,2 \pm 7,0$ \\
\hline & $\begin{array}{l}\text { Imestų metimų iš tolimo nuotolio } \\
\text { skaičius }\end{array}$ & $5,7 \pm 2,3$ & $4,9 \pm 2,0$ & $5,5 \pm 2,4$ & $5,5 \pm 2,0$ \\
\hline & $\begin{array}{l}\text { Mestų metimų iš tolimo nuotolio } \\
\text { skaičius }\end{array}$ & $17,0 \pm 4,5$ & $18,3 \pm 4,3$ & $16,8 \pm 4,7^{*}$ & $19,2 \pm 4,2$ \\
\hline & Tritaškių tikslumas, \% & $33,5 \pm 9,6^{* *}$ & $26,5 \pm 7,4$ & $32,9 \pm 11,2^{*}$ & $28,6 \pm 9,9$ \\
\hline & Imestų baudos metimų skaičius & $12,8 \pm 5,7^{*}$ & $9,3 \pm 4,0$ & $12,1 \pm 5,9$ & $9,5 \pm 3,6$ \\
\hline & Mestų baudos metimų skaičius & $17,6 \pm 7,4^{* * *}$ & $13,4 \pm 5,6$ & $17,0 \pm 7,3^{*}$ & $13,4 \pm 4,8$ \\
\hline & Baudos metimų tikslumas, \% & $74,5 \pm 11,8$ & $70,6 \pm 13,5$ & $73,6 \pm 14,1$ & $73,4 \pm 14,0$ \\
\hline & $\begin{array}{l}\text { Puolimo metu atkovotų kamuolių } \\
\text { skaičius }\end{array}$ & $11,3 \pm 4,2$ & $10,9 \pm 4,9$ & $11,5 \pm 4,7$ & $11,1 \pm 4,5$ \\
\hline & Ginantis atkovotu kamuoliu skaičius & $27,6 \pm 3,4^{* * *}$ & $23,4 \pm 5,1$ & $27,0 \pm 3,7^{* *}$ & $24,1 \pm 5,1$ \\
\hline & Iš viso atkovotų kamuolių skaičius & $38,9 \pm 5,3^{* * *}$ & $34,3 \pm 7,2$ & $38,5 \pm 5,8^{* *}$ & $35,2 \pm 6,8$ \\
\hline & Rezultatyvių perdavimų skaičius & $13,3 \pm 4,0 * *$ & $10,1 \pm 3,4$ & $12,5 \pm 3,8$ & $10,4 \pm 3,6$ \\
\hline & Asmeniniu pražangų skaičius & $16,2 \pm 3,8^{* *}$ & $19,1 \pm 4,0$ & $15,8 \pm 3,4^{* *}$ & $18,7 \pm 3,3$ \\
\hline & Technikos klaidų skaičius & $16,2 \pm 3,9$ & $16,7 \pm 4,5$ & $16,6 \pm 4,4$ & $16,2 \pm 3,8$ \\
\hline \multirow{3}{*}{$\begin{array}{l}\text { Pastaba. Rodikliu skir- } \\
\text { tumai, lyginant laimé- } \\
\text { jusias ir pralaimejjusias } \\
\text { komandas: } *-\mathrm{p}<0,05, \\
* *-\mathrm{p}<0,01, * * *- \\
\mathrm{p}<0,001 .\end{array}$} & Perimtų kamuolių skaičius & $8,9 \pm 3,5$ & $8,0 \pm 2,8$ & $8,6 \pm 3,4$ & $8,0 \pm 2,9$ \\
\hline & Blokuotų kamuolių skaičius & $2,8 \pm 2,4$ & $2,0 \pm 1,6$ & $2,9 \pm 2,1$ & $2,0 \pm 1,5$ \\
\hline & Pelnytų taškų skaičius & $68,2 \pm 7,9 * * *$ & $57,7 \pm 8,3$ & $65,7 \pm 6,6^{*}$ & $60,6 \pm 6,8$ \\
\hline
\end{tabular}

mandų nebuvo nustatyta. Tačiau tritaškių metimu skaičius $(16,8 \pm 4,7$ ir 19,2 $\pm 4,2 ; \mathrm{p}<0,05)$ ir ju tikslumas $(32,9 \pm 11,2$ ir $28,6 \pm 9,9 ; \mathrm{p}<0,05)$ smarkiai skyrèsi tarp komandų. Pergalei itakos turejo ne baudos metimu tikslumas $(73,6 \pm 14,1$ ir $73,4 \pm 14,0 \%$ ), o jų skaičius — komandos nugalètojos kur kas dažniau stojo prie baudos metimų linijos $(17,0 \pm 7,3$ ir $13,4 \pm 4,8 ; \mathrm{p}<0,05)$ ir pelnè daugiau tašku $(12,1 \pm 5,9$ ir $9,5 \pm 3,6$; $\mathrm{p}<0,05)$.

Dèl atšokusių kamuoliu puolimo metu (11,5 \pm 4,7 ir $11,1 \pm 4,5$ ) komandos kovojo panašiai, ir šio rodiklio skirtumas nèra didelis, tačiau ginantis $(27,0 \pm 3,7$ ir $24,1 \pm 5,1 ; p<0,01)$ ir iš viso atkovotų kamuolių skaičiaus rodiklis $(38,5 \pm 5,8$ ir 35,2 $\pm 6,8)$ tarp komandų buvo daug geresnis nugalètojų $(\mathrm{p}<0,01)$ žaidžiant tose rungtynėse, kurios vyko taškas i tašką.

Rungtynèse, kurios baigèsi nedideliu taškų skirtumu ( $1-9$ taškai), kiti kiekybiniai žaidimo rodikliai, tokie kaip asmeniniu pražangu skaičius $(15,8 \pm 3,4$ ir $18,7 \pm 3,3 ; p<0,01)$ turejo itakos siekiant pergalès. Rezultatyvaus perdavimo $(12,5 \pm$ $3,8$ ir 10,4 $\pm 3,6)$, technikos klaidu $(16,6 \pm 3,4$ ir $16,2 \pm 3,8)$, perimtu $(8,6 \pm 3,4$ ir $8,0 \pm 2,9)$ ir blokuotų kamuolių $(2,9 \pm 2,1$ ir $2,0 \pm 1,5)$ skaičiaus rodikliai iš esmès nesiskyrè (1 lent.).

Rungtynių, kurios baigèsi vidutiniu taškų skirtumu - nuo 10 iki $22(\mathrm{n}=17)$, laimejusios ir pralaimejjusios komandos labai skyrèsi 12-ka var- 


\begin{tabular}{|c|c|c|c|c|c|}
\hline \multirow[b]{2}{*}{$\begin{array}{l}\text { Varžybinis } \\
\text { rodiklis }\end{array}$} & \multicolumn{2}{|c|}{$\begin{array}{c}\text { Rungtynių, kurios baigèsi } \\
10-21 \text { taškų skirtumu }(n=17)\end{array}$} & \multicolumn{2}{|c|}{$\begin{array}{c}\text { Rungtynių, kurios baigėsi } \\
22-34 \text { taškų skirtumu }(n=6)\end{array}$} & \multirow{2}{*}{$\begin{array}{l}2 \text { lentelè. Rungtynių, ku- } \\
\text { rios baigèsi } 10-21 \text { ir } \\
22-34 \text { taškų skirtumu, } \\
\text { varžybinių rodiklių ana- } \\
\text { lizé }\end{array}$} \\
\hline & $\begin{array}{l}\begin{array}{l}\text { Laimèjusi } \\
\text { komanda }\end{array} \\
(\bar{x} \pm \mathrm{S})\end{array}$ & $\begin{array}{l}\begin{array}{c}\text { Pralaimèjusi } \\
\text { komanda }\end{array} \\
(\bar{x} \pm S)\end{array}$ & $\begin{array}{l}\begin{array}{l}\text { Laimėjusi } \\
\text { komanda }\end{array} \\
(\bar{x} \pm \mathrm{S})\end{array}$ & $\begin{array}{c}\begin{array}{c}\text { Pralaimėjusi } \\
\text { komanda }\end{array} \\
(\bar{x} \pm \mathrm{S})\end{array}$ & \\
\hline $\begin{array}{l}\text { Imestų metimų iš arti ir vidutinių } \\
\text { nuotolių skaičius }\end{array}$ & $19,7 \pm 4,3^{*}$ & $16,4 \pm 3,8$ & $24,0 \pm 5,4$ & $16,2 \pm 3,1$ & \\
\hline $\begin{array}{l}\text { Mestų metimų iš arti ir vidutinio } \\
\text { nuotolio skaičius }\end{array}$ & $40,1 \pm 5,7$ & $41,2 \pm 7,0$ & $44,6 \pm 7,2$ & $39,6 \pm 4,7$ & \\
\hline Dvitaškių tikslumas, \% & $49,4 \pm 9,5 * * *$ & $39,8 \pm 6,1$ & $53,6 \pm 6,2 *$ & $40,7 \pm 5,2$ & \\
\hline $\begin{array}{l}\text { Imestų metimų iš tolimo nuotolio } \\
\text { skaičius }\end{array}$ & $6,2 \pm 2,3^{*}$ & $4,6 \pm 1,6$ & $5,0 \pm 1,0$ & $2,2 \pm 1,6$ & \\
\hline $\begin{array}{l}\text { Mestų metimų iš tolimo nuotolio } \\
\text { skaičius }\end{array}$ & $17,9 \pm 4,5$ & $17,7 \pm 4,3$ & $14,2 \pm 2,9$ & $14,4 \pm 2,2$ & \\
\hline Tritaškių tikslumas, \% & $34,6 \pm 7,6 * * *$ & $26,3 \pm 9,4$ & $35,5 \pm 5,0^{*}$ & $14,4 \pm 8,2$ & \\
\hline Imestų baudos metimų skaičius & $12,6 \pm 5,9 *$ & $8,4 \pm 4,5$ & $15,2 \pm 2,6$ & $11,4 \pm 3,7$ & \\
\hline Mestų baudos metimų skaičius & $17,2 \pm 8,0^{*}$ & $12,6 \pm 6,7$ & $20,0 \pm 4,4$ & $16,0 \pm 5,3$ & \\
\hline Baudos metimų tikslumas, \% & $74,0 \pm 10,7 * *$ & $65,7 \pm 12,2$ & $76,8 \pm 6,8$ & $71,7 \pm 10,4$ & \\
\hline $\begin{array}{l}\text { Puolimo metu atkovotų kamuolių } \\
\text { skaičius }\end{array}$ & $11,4 \pm 3,9$ & $10,9 \pm 5,6$ & $9,8 \pm 2,2$ & $8,2 \pm 4,9$ & \\
\hline Ginantis atkovotų kamuolių skaičius & $27,9 \pm 3,7 * *$ & $23,0 \pm 5,2$ & $28,8 \pm 2,3$ & $20,2 \pm 3,6$ & \\
\hline Iš viso atkovotų kamuolių skaičius & $39,3 \pm 4,7 *$ & $33,9 \pm 7,7$ & $38,6 \pm 3,5$ & $28,4 \pm 7,4$ & \\
\hline Rezultatyvaus perdavimo skaičius & $14,8 \pm 4,2 * *$ & $10,5 \pm 2,8$ & $16,6 \pm 4,3^{*}$ & $7,0 \pm 2,3$ & \\
\hline Asmeninių pražangų skaičius & $16,2 \pm 4,5^{*}$ & $19,4 \pm 5,2$ & $17,8 \pm 4,1$ & $19,8 \pm 2,9$ & \\
\hline Technikos klaidų skaičius & $15,5 \pm 3,5$ & $16,8 \pm 5,4$ & $16,6 \pm 1,9$ & $20,4 \pm 4,2$ & \\
\hline Perimtų kamuolių skaičius & $9,2 \pm 3,9$ & $8,3 \pm 2,7$ & $11,0 \pm 3,8$ & $8,4 \pm 3,5$ & Pastaba. Rodiklių skir- \\
\hline Blokuotų kamuolių skaičius & $3,1 \pm 3,0$ & $1,8 \pm 1,8$ & $1,2 \pm 1,3$ & $3,2 \pm 2,3$ & $\begin{array}{l}\text { jusias ir pralaiméjusias } \\
\text { komandas: } *-p<0,05 \text {, }\end{array}$ \\
\hline Pelnytų taškų skaičius & $70,6 \pm 8,7 * * *$ & $54,9 \pm 8,5$ & $78,2 \pm 7,1^{*}$ & $50,4 \pm 8,4$ & $\begin{array}{l}* *-\mathrm{p}<0,01, * * *- \\
\mathrm{p}<0,001 .\end{array}$ \\
\hline
\end{tabular}

žybinès veiklos rodiklių. Tokio tipo rungtynèse nugalèjusios komandos pelnè po $70,6 \pm 8,7$, pralaiméjusios - po $54,9 \pm 8,5$ taško. Vidutiniškai tarp komandų buvo 15,7 taško skirtumas $(\mathrm{p}<0,001)$ (2 lent.).

Metimu iš arti, vidutinio $(40,1 \pm 5,7$ ir $41,2 \pm$ $7,0)$ ir tolimo $(17,9 \pm 4,5$ ir $17,7 \pm 4,3)$ nuotolio skaičius tarp laimètojų ir pralaimètojų ryškiai nesiskyrè, tačiau dvitaškių $(49,4 \pm 9,5$ ir $39,8 \pm$ $6,1 \% ; \mathrm{p}<0,001)$ ir tritaškių $(34,6 \pm 7,6$ ir $26,3 \pm$ $9,4 \% ; \mathrm{p}<0,001)$ metimų tikslumas turejo didelès itakos rungtyniu baigčiai. Baudos metimu skaičius $(17,2 \pm 8,0$ ir $12,6 \pm 6,7 ; \mathrm{p}<0,05)$ ir ju tikslumas $(74,0 \pm 10,7$ ir $65,7 \pm 12,2 \% ; p<0,01)$ akivaizdžiai prisidèjo siekiant pergalès.
Dèl atšokusių kamuolių puolant $(11,4 \pm 3,9$ ir $10,9 \pm 5,6)$ komandos, kaip ir itemptose rungtynèse, kovoja panašiai, ir šių rodikliu skirtumas nèra didelis, tačiau ginantis $(27,9 \pm 3,7$ ir $23,0 \pm 5,2$; $\mathrm{p}<0,01)$ ir iš viso atkovotu kamuolių skaičiaus rodiklis $(39,3 \pm 4,7$ ir 33,9 $\pm 7,7)$ buvo kur kas geresnis nugalètoju $(\mathrm{p}<0,05)$.

Kiti kiekybiniai žaidimo rodikliai, tokie kaip rezultatyvus perdavimas $(14,8 \pm 4,2$ ir $10,5 \pm 2,8$; $\mathrm{p}<0,01)$, asmeninès pražangos $(16,2 \pm 4,5 \mathrm{ir}$ $19,4 \pm 5,2 ; p<0,05)$ tų rungtynių, kurios baigèsi vidutiniu $10-21$ taškų skirtumu, kaip ir viso čempionato rungtynèse, turejo itakos siekiant pergalès. O technikos klaidu $(15,5 \pm 3,5$ ir $16,8 \pm 5,4)$, perimtu $(9,2 \pm 3,9$ ir $8,3 \pm 2,7)$ ir blokuotu kamuolių 
$(3,1 \pm 3,0$ ir $1,8 \pm 1,8)$ skaičiaus rodikliai iš esmès nesiskyrè (2 lent.).

Rungtynių, kurios baigèsi 22-34 taškų skirtumu (didžiausias skirtumas rungtynèse), grupe sudare tik 6 rungtynes. Analizuojant varžybinès veiklos rodiklius šio tipo rungtynèse nustatytas nemažas rodiklių skirtumas tarp komandų, tačiau tokių rungtynių buvo nedaug, ir statistinè analizè leido nustatyti tik 4 rodiklius, kurie smarkiai skyrèsi tarp komandų (2 lent.).

\section{REZULTATU APTARIMAS}

Pagrindinis šio tyrimo tikslas buvo nustatyti kritinius žaidimo veiklos rodiklius, kurie skiria laimejusias ir pralaimejusias komandas siekiant galutinio rezultato - pergalès.

Analizuojant visų Europos moterų krepšinio čempionato 2009 metų rungtynių rodiklius $(\mathrm{n}=54)$, buvo nustatyti 10 varžybinès veiklos rodikliu, kurie smarkiai skiriasi, lyginant laimejjusias ir pralaimejjusias komandas. Reikšmingiausi rodiklių skirtumai, lemiantys pergalę buvo šie: pelnomų taškų skaičius ( $p<0,001)$, mestų baudos metimu $(\mathrm{p}<0,001)$, ginantis $(\mathrm{p}<0,001)$ ir iš viso atkovotų kamuolių skaičius $(\mathrm{p}<0,001)$.

Iš 10 varžybinès veiklos rodiklių, ryškiai skyrusių komandas rungtynèse, kurios baigèsi keliu taškų skirtumu $(\mathrm{n}=31)$, nustatyti tik 7 svarbūs.

Svarbiausi žaidimo veiklos rodikliai, lèmę pergalę itemptose rungtynèse, buvo tokie: ginantis ir iš viso atkovotų kamuolių $(\mathrm{p}<0,01)$, tritaškių metimų skaičius $(\mathrm{p}<0,05)$ ir tikslumas $(\mathrm{p}<0,05)$, tiksliu baudos metimų $(\mathrm{p}<0,05)$, rezultatyvaus perdavimo $(\mathrm{p}<0,05)$ ir asmeninių pražangų skaičius $(\mathrm{p}<0,05)$. Visų čempionato rungtynių ir rungtynių, kurios baigèsi nedideliu rodiklių skirtumu, analizè apibendrinta 1 lenteleje.

Analogišku tyrimu G. Csataljay ir kt. (2009) analizavo $2007 \mathrm{~m}$. Europos vyrų čempionato rungtynes. Tarp laimètojų ir pralaimètojų nustatyta 13 akivaizdžiu varžybinès veiklos rodikliu skirtumų. Rungtynèse, kurios baigèsi nedideliu tašku skirtumu (tokiu rungtynių buvo 28) - 6, kurios baigèsi vidutiniu taškų skirtumu (20 rungtyniu) 9 , kurios baigèsi dideliu taškų skirtumu (6 rungtynès) -5 , ryškūs varžybinès veiklos rodiklių skirtumai.

Norint parengti krepšinio komandą rungtynėms, sukurti geriausią taktiką, atlikti tinkamus sprendimus rungtynèse, treneriai turi žinoti, kurie rungtynių elementai yra svarbiausi siekiant pergalès. Ypač tai svarbu, kai rungtynès yra ittemptos, ir tik nedidelis rodiklių skirtumas skiria dvi rungtyniaujančias komandas.

Tokiose rungtynèse, kurios baigèsi $1-9$ tašku skirtumu, komandų nugalètojų buvo mesta kur kas mažiau kartų iš tolimo nuotolio $(p<0,05)$, tačiau šiu metimų tikslumas geresnis nei pralaiméjusių komandu $(\mathrm{p}<0,05)$. Vadinasi, nugalëjusios komandos gynyba sutelkta pavojingiausiuose plotuose arti krepšio ir suteikia galimybę varžovams dažniau mesti iš tolimo nuotolio.

Daugiau atkovotų kamuolių ginantis $(\mathrm{p}<0,01)$ rodo, kad komanda sutelkè dèmesi, gynèsi baudos aikštelès plote atsitverdama varžoves ir užsiimdama geresnę padètị kovodama dèl kamuolio. Komanda nugalètoja kur kas dažniau stojo prie baudos metimo linijos ( $\mathrm{p}<0,01)$, vadinasi, žaidejos buvo veržlios, aktyviai žaide, provokavo varžoves prasižengti, pelnè daugiau tašku ir atitinkamai priartejo prie pergalès. Baudos metimu skaičius per rungtynes rodo komandos aktyvuma organizuojant ir užbaigiant atakas, kai varžovas taiko aktyvios gynybos sistemas, o metimų tikslumas - tiek technikos veiksmų pastovumą, tiek žaidejju psichikos patvarumą, žaidèjų patikimumą (Kreivytè, Čižauskas, 2007).

Daugelis autorių teigia, kad baudos metimu tikslumas daugeliu atvejų lemia rungtynių baigti: paskutiniai taiklūs baudos metimai - rungtynès laimètos, arba atvirkščiai (Vaughn, et al., 1994). R. Pim (1986) teige, kad rungtynių, vykstančiu taškas i tašką, metu komanda, tiksliai metanti baudas, laimi $80 \%$ rungtynių.

Atkovotų kamuolių skaičius ginantis (Mendes, Janeira, 2001; Trninic et al., 2002) ir baudos metimu svarba buvo pabrèžta ankstesniu tyrimų metu (Jukic et al., 2000; Trninic et al., 2002; Sampaio, Janeira, 2003; Oliver, 2004).

Rungtynėse, kurios baigèsi vidutiniu $10-21$ taškų skirtumu, buvo nustatyta 12 akivaizdžių laimejjusių ir pralaimejjusių komandų varžybinès veiklos rodiklių skirtumų. Geresnis metimų $i$ krepši tikslumas - dvitaškiu ( $p<0,001)$, tritaškiu $(\mathrm{p}<0,001)$ ir baudos metimu $(\mathrm{p}<0,01)$, taip pat kova dèl atšokusių kamuoliu puolant $(\mathrm{p}<0,01)-$ komandos sẻkmès raktas.

Kur kas geresnis atkovotu kamuoliu ginantis $(\mathrm{p}<0,01)$ ir rezultatyviai perduotu partnerei kamuoliu skaičius $(p<0,01)$, taip pat geresnis metimu $i$ krepši tikslumas parode, kad puikia gynyba atkovotas nuo krepšio kamuolys komandai nugalètojai suteikia galimybę organizuoti greita puolimą ir pelnyti lengvus taškus. E. Tsamourtzis ir kt. (2005) nustate, kad greitas puolimas ir 
jo veiksmingumas yra svarbūs veiksniai siekiant pergalès.

Rungtynių $(n=6)$, kurios baigėsi dideliu tašku skirtumu (22-34 tašku), buvo nedaug. Jų statistinė analizè leido nustatyti tik 4 ryškiai išsiskiriančius varžybinius rodiklius, skiriančius nugalètojų ir pralaimètojų komandas, nors tarp kitu rodiklių buvo gana didelis skirtumas (2 lent.). Labiausiai komandos skyressi pelnytų taškų skaičiumi $(p<0,05)$, dvitaškių ir tritaškių tikslumu $(\mathrm{p}<0,05)$, rezultatyvaus perdavimo skaičiumi $(\mathrm{p}<0,05)$.

\section{IŠVADOS}

Reikšmingiausi laimejjusių ir pralaimèjusių komandų rodiklių skirtumai viso čempionato rungtynèse buvo šie: pelnomų taškų skaičius $(p<0,001)$, mestų baudos metimu $(p<0,001)$ ir atkovotų kamuolių skaičius ginantis $(\mathrm{p}<0,001)$.

Svarbiausi žaidimo veiklos rodikliai, lèmę pergalę itemptose rungtynėse, buvo tokie: asmeninių pražangų $(\mathrm{p}<0,01)$ ir atkovotų kamuolių skaičius ginantis $(\mathrm{p}<0,01)$. Itemptose rungtynèse laimejjusios komandos mažiau meta iš tolimo nuotolio $(\mathrm{p}<0,05)$, tačiau jų tikslumas geresnis $(\mathrm{p}<0,05)$.

Rungtynès, kurios baigèsi vidutiniu ir dideliu taškų skirtumu rodo, kad laimejjusių komandų rodikliai buvo geresni beveik visais statistiniais žaidimo rodikliais.

\section{LITERATŪRA}

Bartlett, R. (2001). Performance analysis: Can bringing together biomechanics and notational analysis benefit coaches? International Journal of Performance Analysis in Sport, 1, 122-126.

Choi, H., O’Donoghue, P., Hughes, M. D. (2006). A study of team performance indicators by separated time scale real-time analysis techniques within English national league basketball. In Performance Analysis of Sport VII (pp. 138-141). Cardiff: CPA Press, UWIC.

Csataljay, G., O’Donoghue, P., Hughes, M., Dancs, D. (2009). Performance indicators that distinguish winning and losing teams in basketball. International Journal of Performance Analysis of Sport, 9, 60-66.

Hughes, M. D., Bartlett, R. M. (2002). The use of performance indicators in performance analysis. Journal of Sport Sciences, 20, 739-754.

Hughes, M. D., Franks, I. M. (1997). Notational Analysis of Sports. London: E and FN Spon.

Hughes, M. D., Franks, I. M. (2004). Notational Analysis of Sport: Systems for Better Coaching and Performance in Sport. Second edition. London and New York: Routledge.

Hughes, M. D., Franks, I. M. (2008). The Essentials of Performance Analysis - An Introduction. London: Routledge.

Jukic, I., Milanovic, D., Vuleta, D., Bracic, M. (2000). Evaluation of variables of shooting for a goal recorded during the 1997 European Basketball Championship in Barcelona. Kinesiology, 32 (2), 51-62.

Kreivytė, R., Čižauskas, A. (2007). Geriausių pasaulio moterų krepšinio komandų metimų i krepši rodiklių kaita. Ugdymas. Kūno kultūra. Sportas. 2 (65), 30-36.

Lidor, R., Arnon, M. (2000). Developing indexes of efficiency in basketball: Talk with the coaches in their own language. Kinesiology, 32 (2), 31-41.

Mendes, L., Janeira, M. (2001). Basketball performance - multivariate study in Portuguese professional male basketball teams. In Notational Analysis of Sport IV (pp. 103-111). Cardiff: UWIC.

Oliver, D. (2004). Basketball on Pape - Rules and Tools for Performance Analysis. Washington, D. C.: Brassey's Inc.

Pim, R. (1986). The effect of personal fouls on winning and losing basketball games. The Coaching Clinic, 24, $14-16$.

Reano, G. M. A., Calvo, L. A., Toro, O. E. (2006). Differences between winning and losing under-16 male basketball teams. Performance Analysis of Sport VII (pp. 142-149). Cardiff: CPA Press, UWIC.

Sampaio, J., Janeira, M. (2003). Statistical analysis of basketball team performance: Understanding teams' wins and losses according to a different index of ball possessions. International Journal of Performance Analysis in Sport, 3 (1), 40-49.

Sampaio, J., Godoy, S. I., Feu, S. (2004). Discriminative power of basketball game related statistics by level of competition and sex. Perceptual and Motor Skills, 99, $1231-1238$

Tavares, F., Gomes, N. (2003). The offensive process in basketball - a study in high performance junior teams. International Journal of Performance Analysis in Sport, 3 (1), 27-33.

Trninic, S., Dizdar, D., Luksic, E. (2002). Differences between winning and defeated top quality basketball teams in final of European club championship. Collegium Antropologicum, 26 (2), 521-31.

Tsamourtzis, E., Karypidis, A., Athanasiou, N. (2005). Analysis of fast breaks in basketball. International Journal of Performance Analysis in Sport, 5 (2), 17-22.

Vaughn, R. E., Kozar, B., Whitfield, K. E., Lord, R. J., Dye, B. (1994). Importance of free-throws at various stages of basketball games. Perceptual and Motor Skills, $78,243-248$ 


\title{
DIFFERENCES OF INDICATORS IN COMPETITIVE PERFORMANCE BETWEEN WINNING AND LOOSING TEAMS IN BASKETBALL
}

\author{
Rasa Kreivytė, Antanas Čižauskas \\ Lithuanian Academy of Physical Education, Kaunas, Lithuania
}

\begin{abstract}
One of the most important fields of research, alongside with others, in sport science is research in the indicators of sport performance and changes taking place in these indicators on the basis of the results shown at the most important competitions.

To prepare a team for basketball games, to build up the best tactics, to make good decisions during a game, coaches need to know which elements of matches are the most crucial ones. Especially at close games where there is small difference between the performances of two teams.

The main purpose of this study was to identify those critical performance indicators that most distinguish between winning and losing performances within matches. The statistical analysis of basketball matches can lead to the identification of many significant performance indicators, not all of which can be analyzed in real time.

Therefore, a smaller subset of critical performance indicators can be identified by analyzing close matches only. Data from 54 matches were gathered from the official score sheets of the European Basketball Championship 2009.

Cluster analysis was used to classify the matches into three types such as tight games, balanced games and unbalanced games. There were 31 of these matches that were close matches where the differences between the two teams were 9 points or less. Wilcox on signed ranks tests were used to compare 18 performance indicators between the winning and losing teams within each type of match. There were 10 significant performance indicators for the full set of matches. This was reduced to 7 critical performance indicators when only the close matches were considered.

The four most significant ones were the scored points $(\mathrm{p}<0.001)$, the number of successful free throws $(p<0.001)$, the number of defensive rebounds $(p<0.001)$ and total rebounds $(p<0.001)$.

The analysis of tight matches explored that the winning teams had significantly less 3 point attempts $(\mathrm{p}<0.05)$ with higher shooting percentage $(\mathrm{p}<0.05)$.

Results obtained from balanced and unbalanced games show that winning teams made better performance in most of the game statistics.
\end{abstract}

Keywords: basketball, game analysis, performance indicators.

Gauta 2010 m. kovo 15 d.

Received on March 15, 2010

Priimta 2010 m. gegužès $31 \mathrm{~d}$.

Accepted on May 31, 2010
Rasa Kreivytė

Lietuvos kūno kultūros akademija

(Lithuanian Academy of Physical Education)

Sporto g. 6, LT-44221 Kaunas

Lietuva (Lithuania)

Tel +370 37302653

E-mail kreivyte@centras.lt 